\title{
PENGEMBANGAN KOMPUTER PEMBELAJARAN INTERAKTIF MENGGUNAKAN PROGRAM MACROMEDIA DIRECTOR MX 2004 DENGAN MATERI TENSES UNTUK SMP DI BIMBINGAN BELAJAR SANJAYA ENGLISH CLUB JOMBANG
}

\author{
Oleh \\ Sumardi, Muhyiddin, ZA, dan Choirul Anam \\ STMIK Bahrul 'Ulum Tambakberas Jombang
}

\begin{abstract}
ABSTRAK
Peneliti mengembangkan komputer pembelajaran interaktif menggunakan program macromedia director MX 2004. Komputer pembelajaran interaktif biasa disebut dengan istilah CAI yang digunakan dalam kegiatan belajar dengan komputer. "CAI (Computer Assisted Instruction) ialah penggunaan komputer secara langsung dengan siswa untuk menyampaikan isi pelajaran, memberikan latihan-latihan dan mengetes kemajuan belajar siswa." CAI dapat sebagai tutor yang menggantikan guru di dalam kelas. CAI juga bermacam-macam bentuknya bergantung kecakapan pendesain dan pengembang pembelajarannya, bisa berbentuk permainan (games), mengajarkan konsep-konsep abstrak yang kemudian dikonkritkan dalam bentuk visual dan audio yang dianimasikan.

Tujuan dari penelitian ini adalah untuk Mengembangkan Komputer Pembelajaran Interaktif Menggunakan Program Macromedia Director MX 2004 Dengan Materi Tenses Untuk SMP Di Bimbingan Belajar Sanjaya English Club Jombang.

Dari hasil kegiatan penelitian pengembangan dan hasil implementasi media yang telah dilaksanakan. Maka pengembang dapat mengkaji dan menarik kesimpulan terhadap hasil data yang telah diuji cobakan yaitu senilai 73,75\% (Kategori Baik) dalam segi ketepatan isi materi dan segi ketepatan teknik pembuatan, serta dalam segi pemahaman dan kemenarikan program termasuk kategori sangat baik sekali yaitu senilai $\mathbf{8 6 , 2 5 \%}$. Jadi media tersebut tidak perlu direvisi dan siap digunakan dalam proses pembelajaran.
\end{abstract}

Kata Kunci : CAI (Computer Assisted Instruction) Macromedia Director Mx 2004, Tenses

\section{PENDAHULUAN}

\section{Latar Belakang Masalah}

Teknologi merupakan kebutuhan dalam setiap masyarakat. Makin maju suatu masyarakat makin banyak teknologi yang dikembangkan dan digunakan. Banyak diantara kita yang berpendapat bahwa teknologi merupakan solusi atas masalah yang kita hadapi.Tidak terkecuali dalam bidang pendidikan, ada yang menganggap bahwa teknologi akan dapat mengatasi masalah pendidikan yang kita hadapi. "Salah satu masalah pendidikan yang kita hadapi adalah masalah pembelajaran. Masalah ini sangat kompleks, karena meliputi semua unsur atau komponen yang terkait serta pada semua lapis kegiatan, yaitu lapis makro, meso, dan mikro" (Miarso, 2007:542).

Pendidikan sebagai suatu sistem terdiri dari berbagai lapis sistem, makro, meso, dan mikro. Pendidikan nasional merupakan sistem makro atau lapis yang paling atas, seperti masalah pendidikan nasional yaitu ketersediaan kesempatan belajar pada jenjang pendidikan lanjut. Sedangkan pembelajaran di dalam kelas merupakan sistem mikro atau lapis yang paling bawah, seperti masalah yang dihadapi guru dalam satu kelas untuk mata pelajaran tertentu.

Dengan kenyataan ini, bagaimana jika masalah mikro pada Bimbingan Belajar Sanjaya English Club Jombang pada materi Tenses untuk SMP, diselesaikan dengan model pembelajaran bermedia. Karena adanya kesenjangan antara jumlah media belajar dan jumlah siswa dalam bimbingan belajar Sanjaya English Club Jombang dengan materi tenses untuk SMP, maka 
bimbingan belajar dilaksanakan dengan model klasikal, dimana guru menerangkan tenses di depan kelas dengan media papan tulis dan buku panduan saja.

Di satu sisi hal ini akan membantu guru, tetapi di sisi lain siswa akan merasa bosan dan kurang bisa menerima penjelasan guru dengan maksimal. Sehingga diperlukan sebuah media yang sesuai dengan materi dan karakteristik siswa. Keadaan ini dicoba untuk dipecahkan dengan menggunakan pendekatan media komputer pembelajaran interaktif yang dapat meningkatkan penguasaan materi Tenses. Diharapkan materi ini akan lebih maksimal disajikan dengan bahasa visual dan audio dari pada hanya dengan menggunkan bahasa verbal. Media komputer pembelajaran interaktif dipilih oleh peneliti, karena siswa dapat mempergunakannya di luar jam bimbingan belajar bahkan di rumah sekalipun, sehingga dapat mempermudah siswa mempelajarinya.

Peneliti mengembangkan komputer pembelajaran interaktif menggunakan program macromedia director MX 2004. Komputer pembelajaran interaktif biasa disebut dengan istilah CAI yang digunakan dalam kegiatan belajar dengan komputer. "CAI (Computer Assisted Instruction) ialah penggunaan komputer secara langsung dengan siswa untuk menyampaikan isi pelajaran, memberikan latihan-latihan dan mengetes kemajuan belajar siswa." (Anderson, 1994:197). CAI dapat sebagai tutor yang menggantikan guru di dalam kelas. CAI juga bermacam-macam bentuknya bergantung kecakapan pendesain dan pengembang pembelajarannya, bisa berbentuk permainan (games), mengajarkan konsep-konsep abstrak yang kemudian dikonkritkan dalam bentuk visual dan audio yang dianimasikan.

Pemakaian komputer dalam kegiatan pembelajaran untuk tujuan kognitif yaitu komputer dapat mengajarkan konsep-konsep aturan, prinsip, langkah-langkah, proses, dan kalkulasi yang kompleks. Komputer juga dapat menjelaskan konsep tersebut dengan sederhana dengan penggabungan visual dan audio yang dianimasikan. Sehingga cocok untuk kegiatan pembelajaran mandiri.

\section{Rumusan Masalah}

Berdasarkan latar belakang diatas, maka timbul sebuah masalah bahwa diperlukan Pengembangan Komputer Pembelajaran Interaktif Menggunakan Program Macromedia Director MX 2004 Dengan Materi Tenses Untuk SMP Di Bimbingan Belajar Sanjaya English Club Jombang.

\section{Tujuan Pengembangan}

Sesuai dengan latar belakang dan rumusan masalah yang ada, maka tujuan dari penelitian ini adalah untuk Mengembangkan Komputer Pembelajaran Interaktif Menggunakan Program Macromedia Director MX 2004 Dengan Materi Tenses Untuk SMP Di Bimbingan Belajar Sanjaya English Club Jombang.

\section{Manfaat Pengembangan}

Hasil pengembangan ini kiranya akan dapat memberikan beberapa manfaat, antara lain:

1. Bagi lembaga

Pengembangan ini akan menghasilkan sebuah media komputer pembelajaran interaktif yang dapat dimanfaatkan oleh pihak lembaga sebagai media dalam proses pembelajaran untuk usaha meningkatkan penguasaan materi bagi siswa SMP mengenai Tenses.

2. Bagi guru

Hasil pengembangan ini diharapkan dapat dimanfaatkan oleh guru sebagai alternatif pilihan media dalam usaha meningkatkan penguasaan materi bagi siswa SMP mengenai Tenses.

3. Bagi siswa

a. Dapat memperoleh bahan-bahan pembelajaran yang diinginkan sesuai dengan kemampuan 
dan kecepatan belajar yang dimilikinya.

b. Sebagai sumber belajar dan alternatif media pembelajaran yang lain.

4. Bagi peneliti

Proses pengembangan ini akan dapat menjadi sebuah pengalaman praktis yang sangat berharga sebagai usaha realisasi dari teori-teori yang telah diperoleh di bangku perkuliahan.

5. Bagi pengembang atau peneliti lain

Hasil pengembangan ini kiranya dapat digunakan sebagai acuan untuk usaha pengembangan atau penelitian lanjutan.

\section{Asumsi dan Keterbatasan Pengembangan}

\section{Asumsi}

Asumsi adalah anggapan dasar atau sesuatu yang diyakini kebenarannya oleh pengembang dan dijadikan dasar untuk langkah pengembangan.

1. Penggunaan media komputer pembelajaran interaktif memungkinkan materi-materi yang disajikan dapat lebih bermakna dan bertahan lebih lama dalam memori pebelajar.

2. Guru bukanlah satu-satunya sumber belajar, guru merupakan salah satu dari sekian banyak sumber belajar yang memungkinkan siswa untuk belajar.

2. Keterbatasan pengembangan

Agar pengembangan ini lebih maksimal, maka kegiatan penelitian ini akan difokuskan pada:

a. Pengembangan Komputer Pembelajaran Interaktif

b. Menggunakan Program Macromedia Director MX 2004

c. Materi Tenses Untuk SMP

d. Di Bimbingan Belajar Sanjaya English Club Jombang

\section{Spesifikasi Produk yang Diharapkan}

Penelitian pengembangan ini akan menghasilkan sebuah produk media computer pembelajaran interaktif, yaitu:

1. Satu naskah media komputer pembelajaran interaktif sebagai panduan dalam melaksanakan produksi media komputer pembelajaran interaktif.

2. Satu keping VCD dan DVD berisi materi Tenses.

3. Satu bahan penyerta untuk guru yang berisikan panduan mengajar menggunakan media komputer pembelajaran interaktif dan untuk siswa yang berisikan panduan cara belajar menggunakan media komputer pembelajaran interaktif.

\section{TINJAUAN PUSTAKA}

\section{Pengembangan}

"Pengembangan adalah proses penterjemahan spesifikasi desain ke dalam bentuk fisik" (Seels, 1994:38). Di dalam kawasan pengembangan terdapat keterkaitan yang kompleks antara teknologi dan teori yang mendorong baik desain pesan maupun strategi pembelajaran. Pada dasarnya kawasan pengembangan dapat dijelaskan dengan adanya:

a. Pesan yang didorong oleh isi.

b. Strategi pembelajaran yang didorong oleh teori.

c. Manisfestasi fisik dari teknologi-perangkat keras, perangkat lunak dan bahan pembelajaran.

Maka pengembangan merupakan pembuatan media yang digunakan dalam pembelajaran oleh guru sebagai alat bantu dalam memberikan materi. 
Kawasan pengembangan mencakup fungsi-fungsi desain, produksi, dan penyampaian. Maka suatu bahan dapat didesain dengan menggunakan satu jenis teknologi, diproduksi dengan menggunakan yang lain, dan disampaikan dengan menggunakan yang lain lagi.

Kawasan pengembangan dapat diorganisasikan dalam empat kategori:

a. Teknologi cetak

Teknologi cetak adalah cara untuk memproduksi atau menyampaikan bahan, seperti buku-buku dan bahan-bahan visual yang statis, terutama melalui proses pencetakan mekanis atau fotografis.

b. Teknologi audio visual

Teknologi audio visual merupakan cara memproduksi dan menyampaikan bahan dengan menggunakan peralatan mekanis dan elektronis untuk menyajikan pesan-pesan audio dan visual.

c. Teknologi berbasis komputer

Teknologi berbasis komputer merupakan cara-cara memproduksi dan menyampaikan bahan dengan menggunakan perangkat yang bersumber pada mikro prosesor.

d. Teknologi terpadu

Teknologi terpadu merupakan cara untuk memproduksi dan menyampaikan bahan dengan memadukan beberapa jenis media yang dikendalikan komputer.

Penelitian ini masuk dalam domain pengembangan dan terletak pada teknologi berbasis komputer. Karena dalam penelitian ini akan menghasilkan suatu media komputer pembelajaran interaktif yang digunakan dalam kegiatan belajar mengajar dengan tujuan untuk membantu siswa SMP dalam penguasaan materi Tenses.

\section{Komputer pembelajaran interaktif}

"Komputer pembelajaran adalah cara-cara untuk menghasilkan atau menyebarkan materi dengan menggunakan sumber-sumber yang didasarkan pada mikroprosessor" (Seels, 1994:46).

Pemakaian komputer dalam kegiatan pembelajaran untuk tujuan kognitif yaitu komputer dapat mengajarkan konsep-konsep aturan, prinsip, langkah-langkah, proses, dan kalkulasi yang kompleks. Komputer juga dapat menjelaskan konsep tersebut dengan sederhana dengan penggabungan visual dan audio yang dianimasikan. Sehingga cocok untuk kegiatan pembelajaran mandiri.

\section{Program macromedia director MX 2004.}

"Program macromedia director MX 2004 adalah program untuk membuat sebuah karya presentasi multimedia interaktif yang mampu membuat gerakan-gerakan visual serta mengimpor dan mengedit film, memberi narasi serta memasukkan musik" (Thanbrani, 2003:2).

\section{Tenses.}

"Tenses adalah bentuk dari sebuah kata kerja yang menunjukkan waktu terjadinya suatu peristiwa atau perbuatan dan tingkat kesempurnaan suatu kejadian pada waktu dilakukan atau peristiwa yang terjadi (akan dilakukan, sedang terjadi, baru saja dimulai atau telah selesai)" (Huri, 2010:1).

\section{Kerangka Pikiran}

Pendidikan sebagai suatu sistem terdiri dari berbagai lapis sistem, makro, meso, dan mikro. Pendidikan nasional merupakan sistem makro atau lapis yang paling atas, seperti masalah pendidikan nasional yaitu ketersediaan kesempatan belajar pada jenjang pendidikan lanjut. Sedangkan pembelajaran di dalam kelas merupakan sistem mikro atau lapis yang paling bawah, seperti masalah yang dihadapi guru dalam satu kelas untuk mata pelajaran tertentu. Dengan 
kenyataan ini, bagaimana jika masalah mikro pada Bimbingan Belajar Sanjaya English Club Jombang pada materi Tenses untuk SMP, diselesaikan dengan model pembelajaran bermedia.

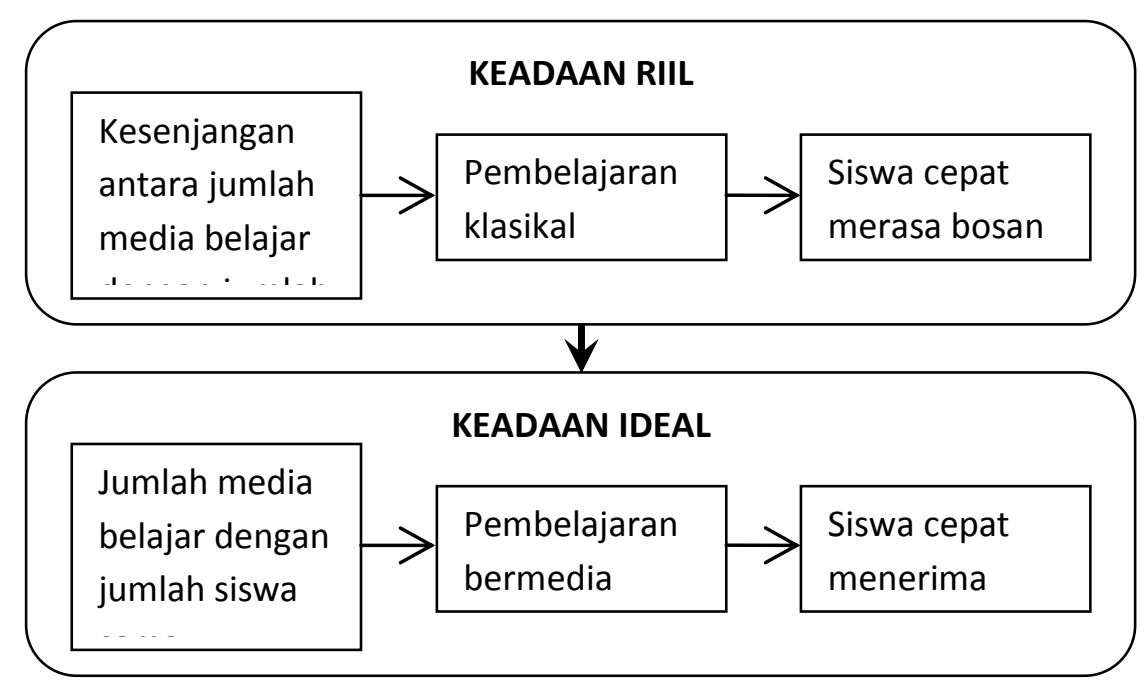

Gambar 1 Bagan Alur Pemikiran

\section{Hipotesis}

Sesuai dengan landasan teori, tinjauan pustaka, dan tujuan penelitian, maka hipotesis penelitian ini yaitu diduga bahwa pengembangan program macromedia director MX 2004 dengan materi tenses untuk SMP di bimbingan belajar sanjaya english club Jombang dapat meningkatkan proses pembelajaran dengan baik.

\section{METODE DAN PROSEDUR PENELITIAN}

Metode penelitian memiliki kedudukan yang penting, karena dengan metode yang tepat akan diperoleh hasil yang diharapkan dan data informasi yang terkumpul juga dapat dipertanggung jawabkan secara ilmiah.

\section{Model Pengembangan}

Model pengembangan media pembelajaran yang dipilih dan digunakan oleh peneliti sebagai landasan dalam kegiatan pengembangan media komputer pembelajaran interaktif, pada materi tenses adalah model pengembangan media dari Arief Sadiman.

Prosedur pengembangan media dari Arief Sadiman (2005:100), sebagai berikut:

1. Menganalisis kebutuhan dan karakteristik siswa.

2. Merumuskan tujuan instruksional (instructional obyektif) dengan operasional dan khas.

3. Merumuskan butir-butir materi secara terperinci yang mendukung tercapainya tujuan.

4. Mengembangkan alat pengukur keberhasilan.

5. Menulis naskah media.

6. Mengadakan tes dan revisi.

Bila langkah-langkah tersebut digambarkan dalam bentuk flow chart, akan diperoleh model pengembangan, sebagai berikut: 


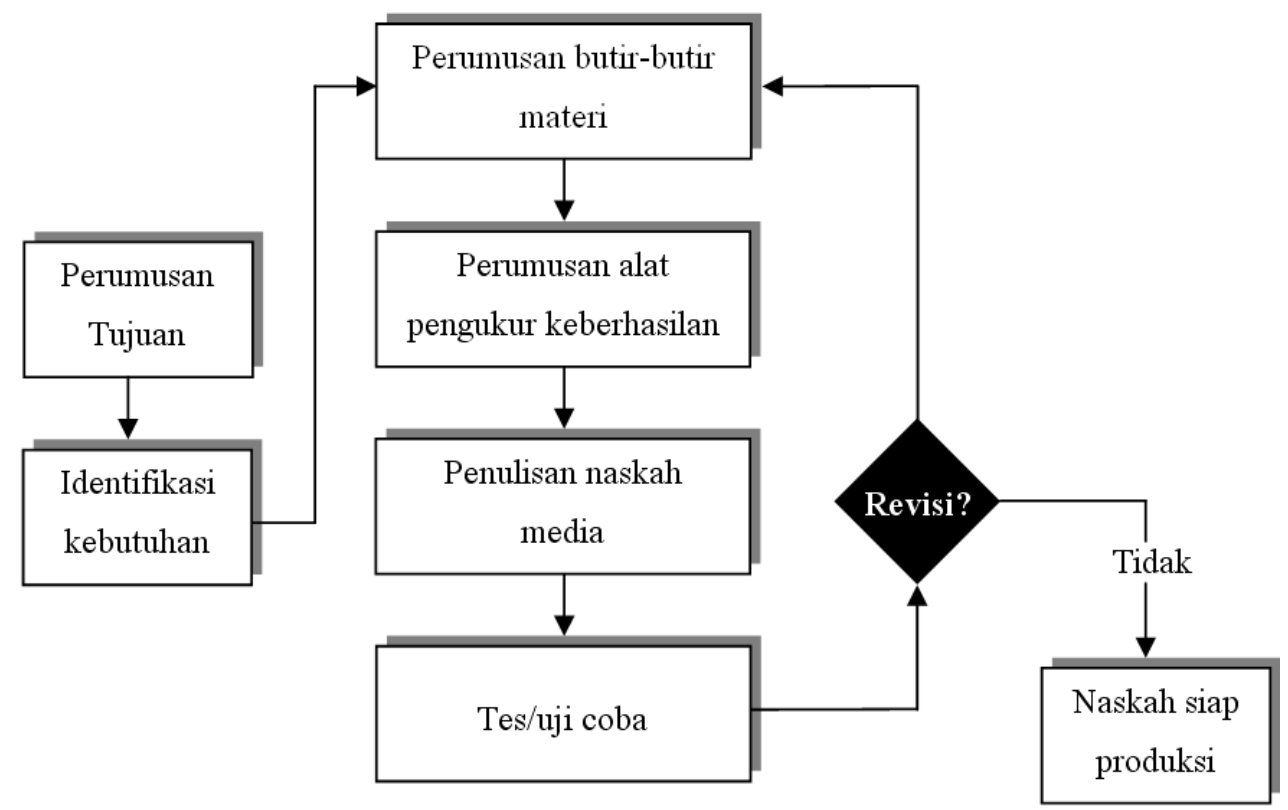

Gambar 2. Model Pengembangan Media Arief Sadiman (2005:101)

\section{Subyek Penelitian}

Dalam suatu penelitian, metode penentuan subyek pengembangan merupakan tahap pertama yang harus ditempuh dan diperhatikan. Subyek pengembangan atau biasa disebut sumber data yakni orang, tempat atau dokumen yang dapat memberikan informasi mengenai data yang dibutuhkan. Subyek pengembangan diklasifikasi menjadi tiga bagian (Arikunto, 2002:107), yaitu:

1. Person yaitu sumber data yang bisa memberikan data berupa jawaban lisan melalui wawancara atau jawaban tertulis melalui angket.

2. Place yaitu sumber data yang menyajikan tampilan berupa keadaan diam dan bergerak. Misalnya lokasi, benda, aktifitas, kinerja dll.

3. Paper yaitu sumber data yang menyajikan tanda-tanda berupa huruf, angka, gambar atau simbol-simbol lain.

Berdasarkan klasifikasi tersebut, maka sumber data dalam penelitian pengembangan ini, sebagai berikut :

1. Person (orang)

a. Ahli materi

Sumber data pertama adalah ahli materi. Ahli materi dipilih peneliti berdasarkan orang yang berkompetensi di bidang materi pembelajaran, peneliti mengambil satu orang ahli materi yaitu pengajar materi Tenses, sebagai sumber data yang diharapkan dapat memberikan informasi mengenai pemahaman materi Tenses pada media komputer pembelajaran interaktif yang dikembangkan. Ahli materi yang dipilih oleh peneliti adalah Budi Sanjaya, S.Pd. 
b. Ahli media

Sumber data kedua adalah ahli media. Peneliti mengambil seorang ahli media, yaitu untuk menilai kualitas teknis media komputer pembelajaran interaktif, yang diharapkan dapat memberikan informasi mengenai kelebihan dan kekurangan media komputer pembelajaran interaktif ditinjau dari kualitas teknis media. Ahli media yang dipilih oleh peneliti adalah Hasan Bisry Isa Alfaris, S.Kom.

c. Siswa

Sumber data ketiga dalam penelitian ini, peneliti mengambil subyek penelitiannya adalah siswa SMP. Jumlah keseluruhan siswa sebanyak 20 siswa. Pengambilan data disesuaikan pada saat penelitian dilakukan yaitu pada semester satu (gasal), disaat kelas tersebut sedang dalam proses pembelajaran Tenses dengan menggunakan media komputer pembelajaran interaktif pada materi Tenses.

Tujuan penelitian terhadap siswa diharapkan dapat memberikan informasi mengenai pemahaman dan kemenarikan program media media komputer pembelajaran interaktif.

2. Place (tempat)

Place (tempat), penelitian pengembangan ini dilaksanakan di Bimbingan Belajar Sanjaya English Club Jombang. Waktu penelitian pengembangan ini dilaksanakan selama semester gasal tahun ajaran 2010-2011.

\section{Obyek Penelitian}

Obyek pengembangan adalah hal yang dikembangkan. Penentuan obyek pengembangan sangat penting untuk membantu memfokuskan pengembangan, menentukan kepada siapa dan bagaimana informasi akan diperoleh serta menentukan bagaimana menganalisis informasi tersebut. Dalam penelitian pengembangan ini yang menjadi obyek pengembangan adalah Media Komputer Pembelajaran Interaktif Menggunakan Program Macromedia Director MX 2004 Dengan Materi Tenses.

\section{Jenis Penelitian}

Disesuaikan dengan permasalahan yang akan diteliti, penelitian ini termasuk penelitian pengembangan. Dalam penelitian ini berhubungan dengan pengembangan media pembelajaran, diteliti dan diadakan penyempurnaan hingga dipilih suatu media yang digunakan dalam pembelajaran oleh guru sebagai alat bantu dalam memberikan materi. Penelitian pengembangan ini menghasilkan suatu produk media pembelajaran yang nantinya siap digunakan dalam kegiatan belajar mengajar sebenarnya.

\section{Sumber Data Penelitian}

Jenis data yaitu data kuantitatif, yakni data yang berwujud dengan angka-angka hasil perhitungan dan pengukuran. Dalam penelitian ini, data kuantitatif diperoleh dari hasil angket.

\section{Teknik Analisis}

Data yang diperoleh dari pengisian angket akan dianalisis dengan menggunakan teknik distribusi frekuansi relatif dan biasa disebut dengan frekuensi relatif, sebab frekuasi yang disajikan disini bukanlah frekuensi yang sebenarnya, melainkan frekuensi yang dituangkan dalam bentuk angka persenan.

$$
\mathrm{p}=\frac{f}{\mathrm{~N}} \times 100 \%
$$


(Sudijono, 2003:40-41)

Keterangan:

$f \quad$ : frekuensi yang sedang dicari persentasenya.

$\mathrm{N}$ : Number of Case (jumlah frekuensi/banyaknya individu).

$\mathrm{p}$ : angka persentase.

Untuk memberikan makna terhadap angka-angka hasil dari teknik tersebut, kriteria penilaiannya adalah sebagai berikut:

$$
\begin{aligned}
& 81 \%-100 \%=\text { Sangat Baik Sekali } \\
& 61 \%-80 \%=\text { Baik } \\
& 41 \%-60 \%=\text { Cukup Baik }
\end{aligned}
$$

(Arthana, 2005:80)

Alternatif penilaian yaitu ada 5 kategori, yaitu sangat baik sekali, baik, cukup baik, kurang baik, dan tidak baik sekali. Pada akhirnya jika media termasuk dalam kategori tidak baik sekali, kurang baik dan cukup baik, maka media tersebut harus direvisi kembali. Dan jika media tersebut termasuk dalam kategori baik dan baik sekali maka media tidak perlu direvisi dan siap digunakan dalam proses pembelajaran.

\section{PEMBAHASAN DAN HASIL PENELITIAN}

Pembahasan dan hasil penelitian, Pengembangan Komputer Pembelajaran Interaktif Menggunakan Program Macromedia Director MX 2004 Dengan Materi Tenses Untuk SMP Di Bimbingan Belajar Sanjaya English Club Jombang.

\section{Gambaran Umum Responden (Objek Penelitian)}

Objek penelitian yaitu Komputer Pembelajaran Interaktif Menggunakan Program Macromedia Director MX 2004 Dengan Materi Tenses Untuk SMP Di Bimbingan Belajar Sanjaya English Club Jombang.

1. Halaman Utama, terdiri dari beberapa menu, yaitu:
a. Petunjuk program
b. Materi 16 program
c. Evaluasi
d. Profil 


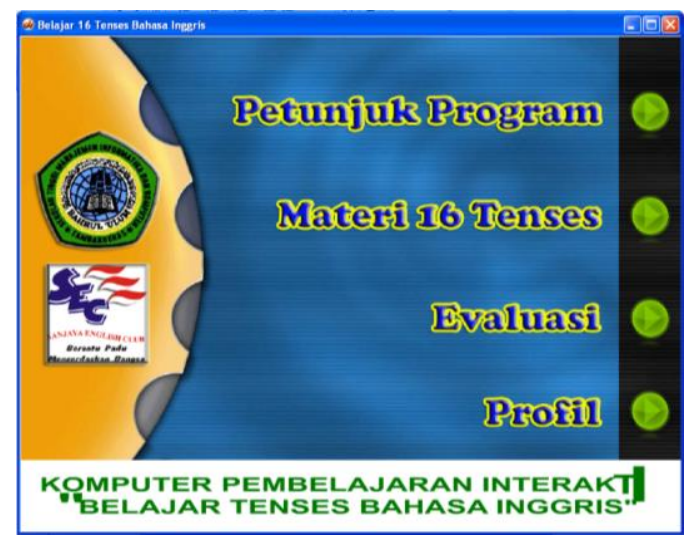

Gambar 3. Profil

2. Menu petunjuk berisi:

a. Petunjuk menggunakan program dan sasaran program
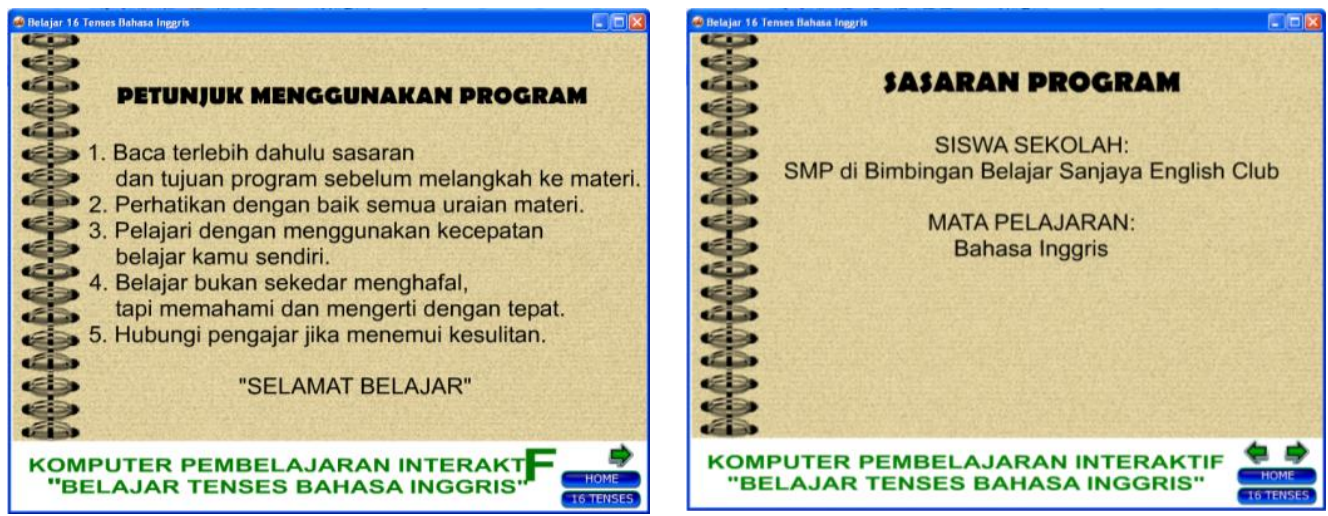

Gambar 4. Petunjuk Menggunakan Program dan sasaran Program

b. Tujuan program

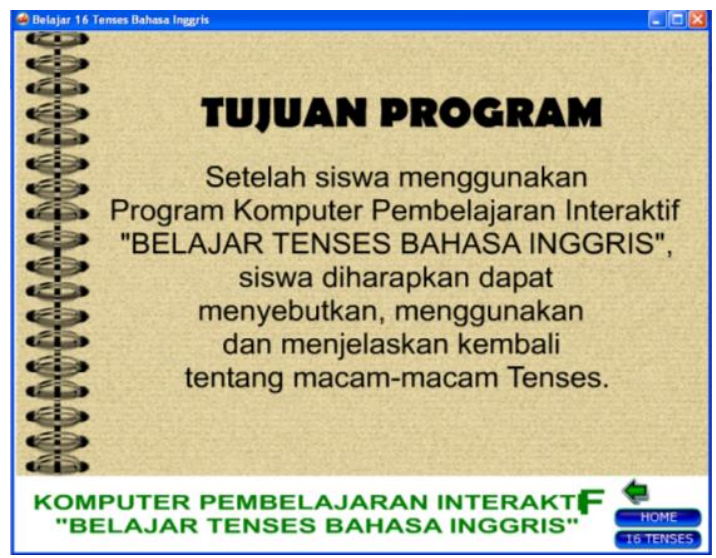

Gambar 5. Tujuan Program 
3. Menu tenses berisi:

a. Pengertian tenses dan 16 Tense
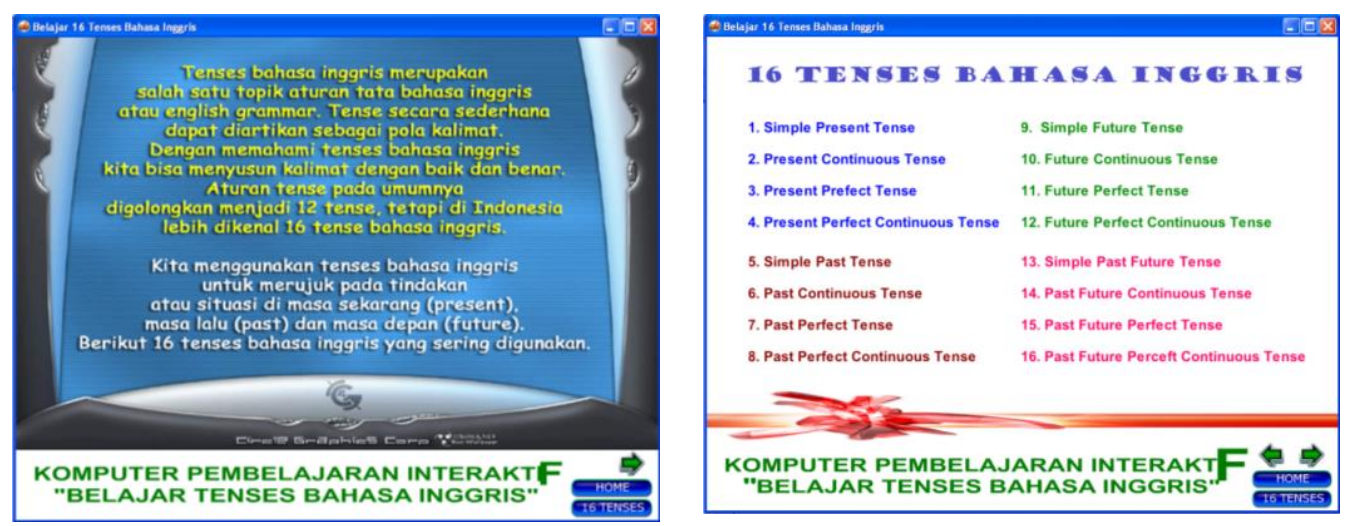

Gambar 6. Pengertian Tenses dan 16 Tense

4. Menu evaluasi berisi:

a. Petunjuk mengerjakan soal
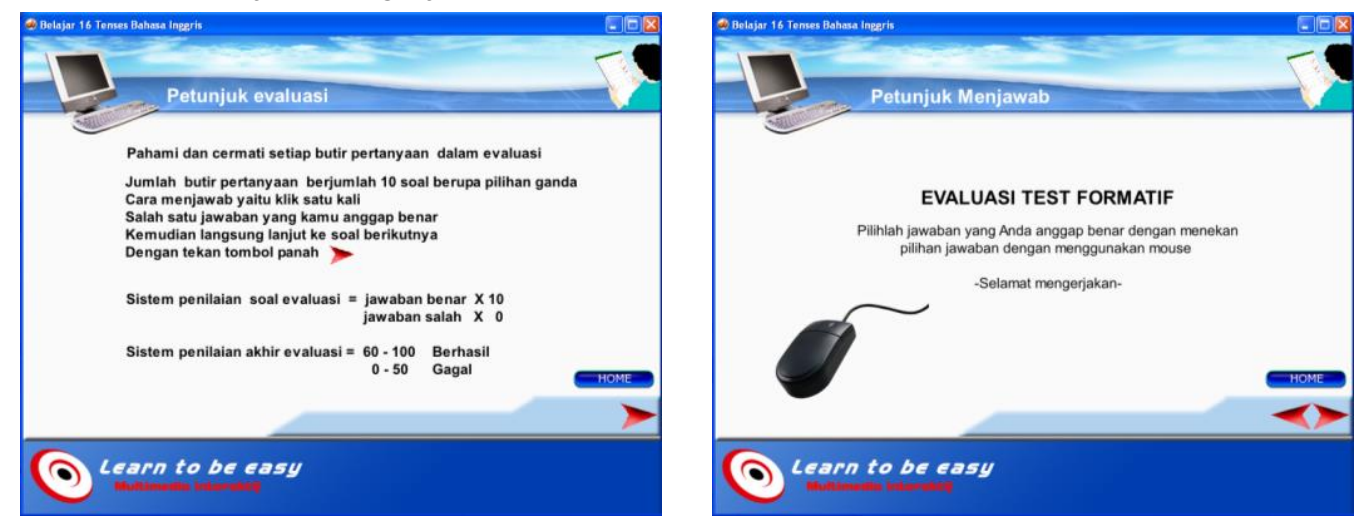

Gambar 7. Petunjuk mengerjakan soal 
5. Menu profil berisi:

Profil pengembang
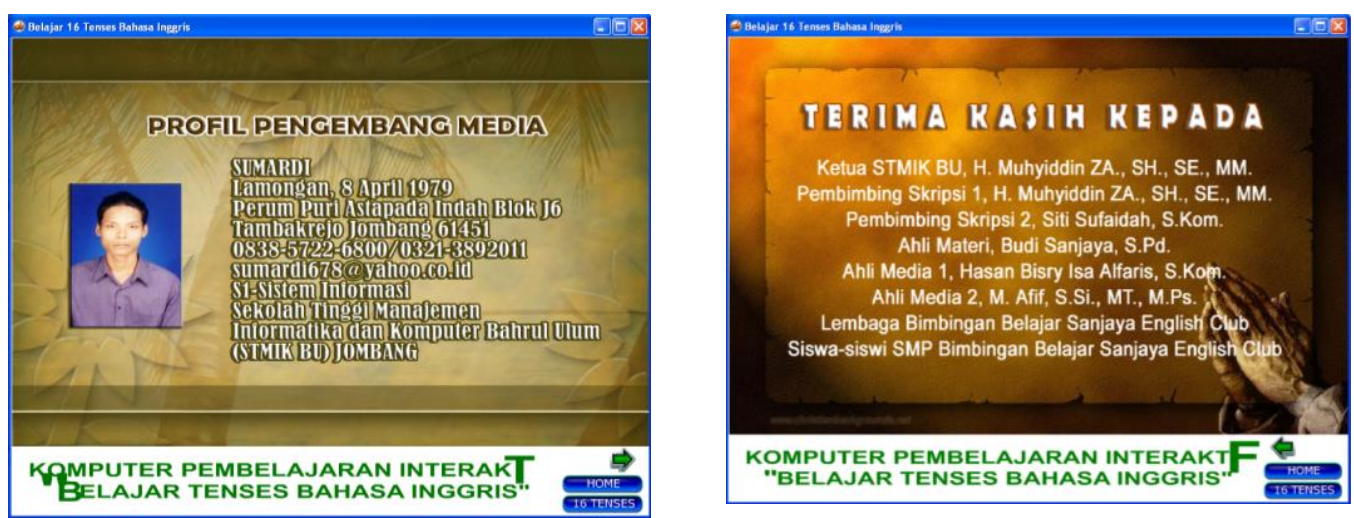

Gambar 8. Profil Pengembangan

\section{Hasil dan Interpretasi Hasil Penelitian dari Ahli Materi dan Ahli Media}

1. Uji coba Ahli Materi ke 1

Review dengan Ahli Materi dan data diambil dari pengisian angket. Biodata Ahli Materi yaitu Budi Sanjaya, S.Pd sebagai Direktur Rumah Cerdas Sanjaya English Club.

Tabel 4.3 Uji Coba 1 Ahli Materi

\begin{tabular}{|c|l|c|c|c|c|l|}
\hline \multirow{2}{*}{ NO. } & \multicolumn{2}{|c|}{ KETERANGAN } & \multicolumn{3}{c|}{ TINGKAT } & \multirow{2}{*}{ KOMENTAR } \\
\cline { 3 - 6 } & & STS & KS & S & SS & \\
\hline 1. & Petunjuk pemakaian program & - & - & $\checkmark$ & - & Tidak perlu diperbaiki \\
\hline 2. & Sasaran program & - & - & $\checkmark$ & - & Tidak perlu diperbaiki \\
\hline 3. & $\begin{array}{l}\text { Tujuan program pada komputer } \\
\text { pembelajaran interaktif }\end{array}$ & - & - & $\checkmark$ & - & Tidak perlu diperbaiki \\
\hline 4. & Pengertian tenses & - & - & $\checkmark$ & - & Tidak perlu diperbaiki \\
\hline 5. & Pola kalimat tenses & - & - & $\checkmark$ & - & Tidak perlu diperbaiki \\
\hline 6. & Contoh tense dalam kalimat & - & - & $\checkmark$ & - & Tidak perlu diperbaiki \\
\hline 7. & Fungsi tenses & - & - & $\checkmark$ & - & Tidak perlu diperbaiki \\
\hline 8. & Keterangan tenses & - & - & $\checkmark$ & - & Tidak perlu diperbaiki \\
\hline 9. & Musik backsound & - & - & $\checkmark$ & - & Tidak perlu diperbaiki \\
\hline 10. & Layout & - & $\checkmark$ & - & - & Warna kurang cerah dan \\
perlu diperbaiki
\end{tabular}


Interpretasi data review dengan Ahli Materi, dengan melihat data pada table di atas dapat diinterpretasikan sebagai berikut:

1. Petunjuk pemakaian program sudah tepat, sehingga tidak perlu diperbaiki.

2. Sasaran program sudah tepat, sehingga tidak perlu diperbaiki.

3. Tujuan program pada komputer pembelajaran interaktif sudah tepat, sehingga tidak perlu diperbaiki.

4. Pengertian tenses sudah tepat, sehingga tidak perlu diperbaiki.

5. Pola kalimat tenses sudah tepat, sehingga tidak perlu diperbaiki.

6. Contoh tenses dalam kalimat sudah tepat, sehingga tidak perlu diperbaiki.

7. Fungsi tenses sudah tepat, sehingga tidak perlu diperbaiki.

8. Keterangan tenses sudah tepat, sehingga tidak perlu diperbaiki.

9. Musik backsound sudah tepat, sehingga tidak perlu diperbaiki.

10. Layout belum tepat dan warna kurang cerah, sehingga perlu diperbaiki.

2. Uji coba Ahli Materi ke 2

Review dengan Ahli Materi dan data diambil dari pengisian angket. Biodata Ahli Materi yaitu Budi Sanjaya, S.Pd sebagai Direktur Rumah Cerdas Sanjaya English Club.

Tabel 4.4 Uji Coba 2 Ahli Materi

\begin{tabular}{|c|l|c|c|c|c|l|}
\hline \multirow{2}{*}{ NO. } & \multirow{2}{*}{ KETERANGAN } & \multicolumn{3}{c|}{ TINGKAT } & \multirow{2}{*}{ KOMENTAR } \\
\cline { 3 - 6 } & & STS & KS & S & SS & \\
\hline 1. & Petunjuk pemakaian program & - & - & $\checkmark$ & - & $\begin{array}{l}\text { Tidak perlu } \\
\text { diperbaiki }\end{array}$ \\
\hline 2. & Sasaran program & - & - & $\checkmark$ & - & $\begin{array}{l}\text { Tidak perlu } \\
\text { diperbaiki }\end{array}$ \\
\hline 3. & $\begin{array}{l}\text { Tujuan program pada komputer } \\
\text { pembelajaran interaktif }\end{array}$ & - & - & $\checkmark$ & - & $\begin{array}{l}\text { Tidak perlu } \\
\text { diperbaiki }\end{array}$ \\
\hline 4. & Pengertian tenses & - & - & $\checkmark$ & - & $\begin{array}{l}\text { Tidak perlu } \\
\text { diperbaiki }\end{array}$ \\
\hline 5. & Pola kalimat tenses & - & - & $\checkmark$ & - & $\begin{array}{l}\text { Tidak perlu } \\
\text { diperbaiki }\end{array}$ \\
\hline 6. & Contoh tense dalam kalimat & - & - & $\checkmark$ & - & $\begin{array}{l}\text { Tidak perlu } \\
\text { diperbaiki }\end{array}$ \\
\hline 7. & Fungsi tenses & - & - & $\checkmark$ & - & $\begin{array}{l}\text { Tidak perlu } \\
\text { diperbaiki }\end{array}$ \\
\hline 8. & Keterangan tenses & - & - & $\checkmark$ & - & $\begin{array}{l}\text { Tidak perlu } \\
\text { diperbaiki }\end{array}$ \\
\hline 9. & Musik backsound & - & - & $\checkmark$ & - & $\begin{array}{l}\text { Tidak perlu } \\
\text { diperbaiki }\end{array}$ \\
\hline 10. & Layout & - & - & $\checkmark$ & - & $\begin{array}{l}\text { Tidak perlu } \\
\text { diperbaiki }\end{array}$ \\
\hline
\end{tabular}

Interpretasi data review dengan Ahli Materi, dengan melihat data pada table di atas dapat diinterpretasikan sebagai berikut: 
1. Petunjuk pemakaian program sudah tepat, sehingga tidak perlu diperbaiki.

2. Sasaran program sudah tepat, sehingga tidak perlu diperbaiki.

3. Tujuan program pada komputer pembelajaran interaktif sudah tepat, sehingga tidak perlu diperbaiki.

4. Pengertian tenses sudah tepat, sehingga tidak perlu diperbaiki.

5. Pola kalimat tenses sudah tepat, sehingga tidak perlu diperbaiki.

6. Contoh tenses dalam kalimat sudah tepat, sehingga tidak perlu diperbaiki.

7. Fungsi tenses sudah tepat, sehingga tidak perlu diperbaiki.

8. Keterangan tenses sudah tepat, sehingga tidak perlu diperbaiki.

9. Musik backsound sudah tepat, sehingga tidak perlu diperbaiki.

10. Layout sudah tepat, sehingga tidak perlu diperbaiki.

3. Uji coba Ahli Media

Review dengan Ahli Media dan data diambil dari pengisian angket. Biodata Ahli Media yaitu Hasan Bisry Isa Alfaris, S.Kom sebagai Dosen mata kuliah Rekayasa Sistem Informasi.

Tabel 4.5 Uji Coba Ahli Media

\begin{tabular}{|c|l|c|c|c|c|l|}
\hline \multirow{2}{*}{ NO. } & \multirow{2}{*}{ KETERANGAN } & \multicolumn{3}{|c|}{ TINGKAT } & \multirow{2}{*}{ KOMENTAR } \\
\cline { 3 - 6 } & & STS & KS & S & SS & \\
\hline 1. & $\begin{array}{l}\text { Petunjuk pemakaian } \\
\text { program }\end{array}$ & - & - & $\checkmark$ & - & Tidak perlu diperbaiki \\
\hline 2. & Sasaran program & - & - & $\checkmark$ & - & $\begin{array}{l}\text { Hilangkan tahun ajaran } \\
\text { sehingga bisa digunakan } \\
\text { selamanya }\end{array}$ \\
\hline 3. & $\begin{array}{l}\text { Tujuan program pada } \\
\text { komputer pembelajaran } \\
\text { interaktif }\end{array}$ & - & - & $\checkmark$ & - & Tidak perlu diperbaiki \\
\hline 4. & Pengertian tenses & - & - & $\checkmark$ & - & Tidak perlu diperbaiki \\
\hline 5. & Pola kalimat tenses & - & - & $\checkmark$ & - & Tidak perlu diperbaiki \\
\hline 6. & $\begin{array}{l}\text { Contoh tense dalam } \\
\text { kalimat }\end{array}$ & - & - & $\checkmark$ & - & Tidak perlu diperbaiki \\
\hline 7. & Fungsi tenses & - & - & $\checkmark$ & - & Tidak perlu diperbaiki \\
\hline 8. & Keterangan tenses & - & $\checkmark$ & - & - & $\begin{array}{l}\text { Berikan penjelasan pada } \\
\text { jawaban yang ada dan } \\
\text { soal bersifat tetap }\end{array}$ \\
\hline 9. & Musik backsound & - & - & $\checkmark$ & - & Tidak perlu diperbaiki \\
\hline 10. & Layout & - & - & $\checkmark$ & - & Tidak perlu diperbaiki \\
\hline
\end{tabular}

Interpretasi data review dengan Ahli Media, dengan melihat data pada table di atas dapat diinterpretasikan sebagai berikut:

1. Petunjuk pemakaian program sudah tepat, sehingga tidak perlu diperbaiki.

2. Sasaran program sudah tepat, sehingga tidak perlu diperbaiki.

3. Tujuan program pada komputer pembelajaran interaktif sudah tepat, tapi masih perlu diperbaiki, yaitu hilangkan tahun ajaran sehingga bisa digunakan selamanya. 
4. Pengertian tenses sudah tepat, sehingga tidak perlu diperbaiki.

5. Pola kalimat tenses sudah tepat, sehingga tidak perlu diperbaiki.

6. Contoh tenses dalam kalimat sudah tepat, sehingga tidak perlu diperbaiki.

7. Fungsi tenses sudah tepat, sehingga tidak perlu diperbaiki.

8. Keterangan tenses belum tepat, sehingga perlu diperbaiki, yaitu berikan penjelasan pada jawaban yang ada dan soal bersifat tetap.

9. Musik backsound sudah tepat, sehingga tidak perlu diperbaiki.

10. Layout sudah tepat, sehingga tidak perlu diperbaiki.

4. Perhitungan angket dari Ahli Materi dan Ahli Media

Tabel 4.6 Tingkat Penilaian dan Frekuensi Jawaban Ahli Materi dan Ahli Media

\begin{tabular}{|c|c|c|c|c|}
\hline \multirow{2}{*}{ Nomor Soal } & \multicolumn{5}{|c|}{ Tingkat Penilaian dan Frekuensi Jawaban } \\
\cline { 2 - 5 } & STS (1) & KS (2) & S (3) & SS (4) \\
\hline 1 & - & - & 2 & - \\
\hline 2 & - & - & 2 & - \\
\hline 3 & - & - & 2 & - \\
\hline 4 & - & - & 2 & - \\
\hline 5 & - & - & 2 & - \\
\hline 6 & - & - & 2 & - \\
\hline 7 & - & - & 2 & - \\
\hline 8 & - & 1 & 1 & - \\
\hline 9 & - & - & 2 & - \\
\hline 10 & - & - & 2 & - \\
\hline
\end{tabular}

Rumus:

$p=f \times 100 \%$

$n$

Keterangan:

$f \quad$ : frekuensi yang sedang dicari persentasenya.

$\mathrm{N}$ : Number of Case (jumlah frekuensi/banyaknya individu).

$\mathrm{p} \quad$ : angka persentase.

1. $(3 \times 2) \times 100 \%$

$(4 \times 2)$

2. $\quad(3 \times 2) \times 100 \%$

$(4 \times 2)$

3. $(3 \times 2) \times 100 \%$

$(4 \times 2)$

4. $(3 \times 2) \times 100 \%$ $=\frac{6}{8} \times 100 \%=0,75 \times 100 \%=75 \%$

$=\underline{6} \times 100 \%=0,75 \times 100 \%=75 \%$

$=\underline{6} \times 100 \%=0,75 \times 100 \%=75 \%$

$=\underline{6} \times 100 \%=0,75 \times 100 \%=75 \%$ 
$(4 \times 2)$

5. $(3 \times 2) \times 100 \%$

$(4 \times 2)$

6. $(3 \times 2) \times 100 \%$ $(4 \times 2)$

7. $(3 \times 2) \times 100 \%$ $(4 \times 2)$

8

$$
\begin{array}{ll}
=\underline{6} \times 100 \%=0,75 \times 100 \%=75 \% \\
=\underline{6} \times 100 \%=0,75 \times 100 \%=75 \% \\
=\underline{6} \times 100 \%=0,75 \times 100 \%=75 \%
\end{array}
$$

8. $\underline{(3 \times 1)+(2 \times 1)} \times 100 \%=\underline{5} \times 100 \%=0,625 \times 100 \%=62,5 \%$ $(4 \times 2)$ 8

9. $\quad(3 \times 2) \times 100 \%$ $(4 \times 2)$

$$
\begin{array}{ll}
=\underline{6} \times 100 \%=0,75 \times 100 \%=75 \% \\
=\underline{6} \times 100 \%=0,75 \times 100 \%=75 \%
\end{array}
$$

Perhitungan rerata $=\mathbf{7 5 \%}+75 \%+75 \%+75 \%+75 \%+75 \%+75 \%+62,5 \%+75 \%+75 \%$

$$
\begin{aligned}
& =\underline{737,5} \\
& 10 \\
& =\mathbf{7 3 , 7 5 \%} \text { (Kategori Baik) }
\end{aligned}
$$

Jadi Program Komputer Pembelajaran Interaktif Menggunakan Dengan Materi Tenses Untuk SMP dalam segi ketepatan isi materi dan segi ketepatan teknik pembuatan termasuk kategori baik.

\section{Hasil dan Interpretasi Hasil Penelitian dari Ahli Materi dan Ahli Media}

1. Uji coba siswa SMP

Review dengan 20 siswa SMP dan data diambil dari pengisian angket. Biodata 20 siswa SMP di Bimbingan Belajar Sanjaya English Club, yaitu:

Tabel 4.7 Data 20 Siswa SMP

\begin{tabular}{|l|l|l|l|l|l|}
\hline NO. & NAMA SISWA & KELAS & NO. & NAMA SISWA & KELAS \\
\hline 1. & Aan Ainuz Zubaidah & VII & 11. & Aimmatul Mujahidah & VIII \\
\hline 2. & Dina Rohmatul & VII & 12. & Anggi Azizah & VIII \\
\hline 3. & Elisa Aprilia & VII & 13. & Imamah Nurun Najah & VIII \\
\hline 4. & Faizatul Luthfiyah & VII & 14. & Lailatul Fitriyah & VIII \\
\hline 5. & Jumini & VII & 15. & Siti Luthfiyah & VIII \\
\hline 6. & Khoirum Anisah & VII & 16. & Siti Rodhiyah & VIII \\
\hline 7. & Linda Irmayanti & VII & 17. & Yunia Muflihah & VIII \\
\hline 8. & Nazilatur Rohmah & VII & 18. & Azel Hidayatul & IX \\
\hline 9. & Nur Laily Al-Adawy & VII & 19. & Kartika Wulansari & IX \\
\hline 10. & Zumrotus Sholikhah & VII & 20. & Putri Hikamtul & IX \\
\hline
\end{tabular}


2. Perhitungan angket dari Siswa

Tabel 4.8 Tingkat Penilaian dan Frekuensi Jawaban 20 Siswa

\begin{tabular}{|c|c|c|c|c|}
\hline \multirow{2}{*}{ Nomor Soal } & \multicolumn{4}{|c|}{ Tingkat Penilaian dan Frekuensi Jawaban } \\
\hline & STS (1) & KS (2) & S (3) & SS (4) \\
\hline 1 & - & - & 9 & 11 \\
\hline 2 & - & 3 & 5 & 12 \\
\hline 3 & - & - & 13 & 7 \\
\hline 4 & - & - & 6 & 14 \\
\hline \multirow{2}{*}{ Nomor Soal } & \multicolumn{4}{|c|}{ Tingkat Penilaian dan Frekuensi Jawaban } \\
\hline & STS (1) & KS (2) & S (3) & SS (4) \\
\hline 5 & - & - & 15 & 5 \\
\hline 6 & - & - & 10 & 10 \\
\hline 7 & - & 2 & 11 & 7 \\
\hline 8 & - & - & 8 & 12 \\
\hline 9 & - & - & 11 & 9 \\
\hline 10 & - & 1 & 10 & 9 \\
\hline
\end{tabular}

Rumus:

$$
p=f \times 100 \%
$$

Keterangan:

$f \quad$ : frekuensi yang sedang dicari persentasenya.

$\mathrm{N}$ : Number of Case (jumlah frekuensi/banyaknya individu).

p : angka persentase.

1. $\frac{(3 \times 9)+(4 \times 11)}{(4 \times 20)}$

$$
\begin{aligned}
x 100 \%=\frac{27+44}{80} \quad \times 100 \%=\frac{71}{80} \times 100 \% \\
=0,8875 \quad \times 100 \%=\mathbf{8 8 , 7 5 \%}
\end{aligned}
$$

2. $(2 \times 3)+(3 \times 5)+(4 \times 12)$ $(4 \times 20)$

$$
\mathrm{x} 100 \%=\frac{6+15+48}{80} \times 100 \%=\underline{69} \times 100 \%
$$$$
=0,8625 \times 100 \%=\mathbf{8 6 , 2 5 \%}
$$

3. $(3 \times 13)+(4 \times 7)$ $(4 \times 20)$

$$
x 100 \%=\underline{39+28} \times 100 \%=\underline{67} \times 100 \%
$$$$
=0,8375 \times 100 \%=\mathbf{8 3 , 7 5 \%}
$$

4. $\quad(3 \times 6)+(4 \times 14)$ $(4 \times 20)$

$$
\begin{aligned}
\mathrm{x} 100 \%=\frac{18+56}{80} & \times 100 \%=\frac{74}{80} \times 100 \% \\
& =0,925 \quad \times 100 \%=\mathbf{9 2 , 5 \%}
\end{aligned}
$$



5. $(3 \times 15)+(4 \times 5)$
$(4 \times 20)$
$x 100 \%=\frac{45+20}{80} \quad \times 100 \%=\underline{65} \times 100 \%$
$=0,8125 \times 100 \%=\mathbf{8 1 , 2 5 \%}$
6. $\frac{(3 \times 10)+(4 \times 10)}{(4 \times 20)}$
$x 100 \%=\frac{30+40}{80} \quad \times 100 \%=\frac{70}{80} \times 100 \%$
$=0,875$
$\mathrm{x} 100 \%=\mathbf{8 7 , 5} \%$
7. $\frac{(2 \times 2)+(3 \times 11)+(4 \times 7)}{(4 \times 20)}$
$\mathrm{x} 100 \%=\frac{4+33+28}{80} \times 100 \%=\frac{65}{80} \times 100 \%$
$=0,8125 \times 100 \%=\mathbf{8 1 , 2 5 \%}$
8. $\frac{(3 \times 8)+(4 \times 12)}{(4 \times 20)}$
$x 100 \%=\frac{24+48}{80} \quad \times 100 \%=\underline{72} \times 100 \%$
$=0,9$
$\mathrm{x} 100 \%=\mathbf{9 0 \%}$
9. $\frac{(3 \times 11)+(4 \times 9)}{(4 \times 20)}$
$x 100 \%=\frac{33+36}{80} \quad \times 100 \%=\underline{69} \times 100 \%$
$=0,8625 \times 100 \%=\mathbf{8 6 , 2 5 \%}$
10. $\frac{(2 \times 1)+(3 \times 10)+(4 \times 9)}{(4 \times 20)}$
$\mathrm{x} 100 \%=\frac{2+30+36}{80} \times 100 \%=\underline{68} \times 100 \%$
$=0,85 \quad x 100 \%=\mathbf{8 5} \%$

Perhitungan rerata

$=88,75 \%+86,25 \%+83,75 \%+92,5 \%+81,25 \%+87,5 \%+81,25 \%+90 \%+86,25 \%+85 \%$

10

$=\underline{862,5}$

10

$=86,25 \%$ (Kategori Sangat Baik Sekali)

Jadi Program Komputer Pembelajaran Interaktif Menggunakan Dengan Materi Tenses Untuk SMP dalam segi pemahaman dan kemenarikan program termasuk kategori sangat baik sekali.

\section{KESIMPULAN DAN SARAN}

\section{Kesimpulan}

Dari hasil kegiatan penelitian pengembangan dan hasil implementasi media yang telah dilaksanakan. Maka pengembang dapat mengkaji dan menarik kesimpulan terhadap hasil data yang telah diuji cobakan yaitu senilai 73,75\% (Kategori Baik) dalam segi ketepatan isi materi dan segi 
ketepatan teknik pembuatan, serta dalam segi pemahaman dan kemenarikan program termasuk kategori sangat baik sekali yaitu senilai $\mathbf{8 6 , 2 5 \%}$. Jadi media tersebut tidak perlu direvisi dan siap digunakan dalam proses pembelajaran.

\section{Saran}

\section{Saran pemanfaatan}

Bagi pihak-pihak pemakai media ini diharapkan dapat memperhatikan beberapa hal dalam pemanfaatan media komputer pembelajaran interaktif ini.

a. Guru

Setelah selesai menggunakan komputer pembelajaran interaktif ini, usahakan untuk selalu mengadakan diskusi, baik diskusi kelas maupun dalam kelompok kecil mengenai materi yang baru saja disajikan.

b. Siswa

Ada baiknya jika menemui kesulitan dalam memahami media komputer pembelajaran interaktif ini, untuk segera berkonsultasi kepada yag berwenang, yang dalam hal ini adalah Guru pengajar mata pelajaran Bahasa Inggris.

c. Lembaga pendidikan

Ada baiknya agar media komputer pembelajaran interaktif ini dikembangkan juga untuk materi mata pelajaran yang lain.

\section{Saran pengembangan}

Bahwa program Komputer Pembelajaran Interaktif Belajar Tenses Bahasa Inggris ini masih jauh dari sempurna, untuk itu dapat dikembangkan oleh peneliti selanjutnya.

\section{DAFTAR PUSTAKA}

Anderson, Ronald H. 1994. Pemilihan dan Pengembangan Media Untuk Pembelajaran. Jakarta: PT RajaGrafindo Persada.

Biro Administrasi Akademik Kemahasiswaan. 2010. Pedoman Penulisan Skripsi. Jombang: STMIK Bahrul Ulum Jombang.

Arikunto, Suharsimi. 2002. Prosedur Penelitian Suatu Pendekatan Praktek. Jakarta: PT. Rineka Cipta.

Arthana, I Ketut Pegig dan Damajanti Kusuma. 2005. Evaluasi Media Pembelajaran. Surabaya: Teknologi Pendidikan-Unesa.

Huri, Agus Daman. 2010. The Understanding Grammar. Jombang: Ex Bec Teacher.

Larasati, Peni. 2009. Bahas Tuntas 1001 Soal Bahasa Inggris SMP/Forum Tentor. Yogyakarta: Pustaka Widyatama.

Madcom. 2004. Seri Panduan Lengkap Macromedia Director MX 2004. Yogyakarta: Andi.

Miarso, Yusufhadi. 2007. Menyemai Benih Teknologi Pendidikan. Jakarta: Kencana. 
Sadiman, Arief S. dkk. 2005. Media Pendidikan Pengertian, Pengembangan, dan Pemanfaatannya. Jakarta: RajaGrafindo Persada.

Seels, Barbara B. dan Rita C. Richey. 1994. Teknolgi Pembelajaran Definisi dan Kawasannya. Jakarta: Universitas Negeri Jakarta.

Sudijono, Anas. 2003. Pengantar Statistik Pendidikan. Jakarta: PT RajaGrafindo Persada.

Susarno, Lamijan Hadi. 2005. Teknik Penulisan Karya Ilmiah Untuk Seminar Teknologi Pendidikan. Surabaya: Universitas Negeri Surabaya.

Thabrani, Suryanto dan Seno Adjie. 2003. Macromedia Director 8.5. Jakarta: Salemba Infotek. 